\title{
High-intensity interval training versus moderate- intensity continuous training within cardiac rehabilitation: a systematic review and meta-analysis
}

This article was published in the following Dove Press journal:

Open Access Journal of Sports Medicine

\author{
Amanda L Hannan' \\ Wayne Hing' \\ Vini Simas' \\ Mike Climstein ${ }^{2,3}$ \\ Jeff S Coombes ${ }^{4}$ \\ Rohan Jayasinghe ${ }^{5-7}$ \\ Joshua Byrnes ${ }^{8}$ \\ James Furness ${ }^{1}$
}

'Faculty of Health Sciences \& Medicine, Bond University, Gold Coast, QLD, Australia; ${ }^{2}$ Exercise Health and Performance Faculty Research Group, Faculty of Health Sciences, The University of Sydney, Sydney, NSW, Australia; ${ }^{3}$ Water Based Research Unit, Bond University, Gold Coast, QLD, Australia;

${ }^{4}$ School of Human Movement and Nutrition Sciences, The University of Queensland, Brisbane, QLD, Australia; ${ }^{5}$ Cardiology Department, Gold Coast University Hospital, Gold Coast, QLD, Australia; ' $\mathrm{G}$ riffith University, Gold Coast, QLD, Australia; ${ }^{7}$ Macquarie University, Sydney, NSW, Australia; ${ }^{8}$ Centre for Applied Health Economics, School of Medicine, Griffith University, Logan, QLD, Australia

Correspondence: Amanda L Hannan Faculty of Health Sciences \& Medicine, Bond University, 2 Promethean Way, Robina, Gold Coast, QLD 4226, Australia $\mathrm{Tel}+6 \mid 4$ I55। 0772

Fax+6I 755951652

Emailmhannan@bond.edu.au
Background: Aerobic capacity has been shown to be inversely proportionate to cardiovascular mortality and morbidity and there is growing evidence that high-intensity interval training (HIIT) appears to be more effective than moderate-intensity continuous training (MICT) in improving cardiorespiratory fitness within the cardiac population. Previously published systematic reviews in cardiovascular disease have neither investigated the effect that the number of weeks of intervention has on cardiorespiratory fitness changes, nor have adverse events been collated. Objective: We aimed to undertake a systematic review and meta-analysis of randomized controlled trials (RCTs) within the cardiac population that investigated cardiorespiratory fitness changes resulting from HIIT versus MICT and to collate adverse events.

Methods: A critical narrative synthesis and meta-analysis was conducted after systematically searching relevant databases up to July 2017. We searched for RCTs that compared cardiorespiratory fitness changes resulting from HIIT versus MICT interventions within the cardiac population. Results: Seventeen studies, involving 953 participants (465 for HIIT and 488 for MICT) were included in the analysis. HIIT was significantly superior to MICT in improving cardiorespiratory fitness overall (SMD $0.34 \mathrm{~mL} / \mathrm{kg} / \mathrm{min} ; 95 \%$ confidence interval [CI; 0.2-0.48]; $p<0.00001$; $I^{2}=28 \%$ ). There were no deaths or cardiac events requiring hospitalization reported in any study during training. Overall, there were more adverse events reported as a result of the MICT $(n=14)$ intervention than the HIIT intervention $(n=9)$. However, some adverse events $(n=5)$ were not classified by intervention group.

Conclusion: HIIT is superior to MICT in improving cardiorespiratory fitness in participants of cardiac rehabilitation (CR). Improvements in cardiorespiratory fitness are significant for CR programs of $>6$-week duration. Programs of 7-12 weeks' duration resulted in the largest improvements in cardiorespiratory fitness for patients with coronary artery disease. HIIT appears to be as safe as MICT for CR participants.

Keywords: coronary artery disease, cardiac rehabilitation, interval training, exercise, intensity, physical therapy, cardiovascular disease

\section{Introduction}

Coronary heart disease (CHD) results in one in four deaths globally - an increase from one in five deaths 20 years ago. ${ }^{1}$ A systematic analysis for the Global Burden of Disease Study in 2012 ranked CHD as the leading cause of years of life lost (YLL) to premature death surpassing lower respiratory infections. In the last 20 years, YLL attributed to CHD has increased by $28 \%{ }^{1}$ 
Cardiac rehabilitation (CR) is an important tool in secondary prevention of cardiovascular disease. It aims to assist participants to lead full, healthy lives, while reducing the likelihood of suffering subsequent cardiac incidents. ${ }^{2,3}$ CR involves education, lifestyle behavior modification, psychosocial support, and supervised exercise programs. ${ }^{4,5}$ These exercise programs aim to increase the cardiorespiratory fitness and muscular strength of CR participants; however, international $\mathrm{CR}$ guidelines are inconsistent in their recommendations concerning exercise intensity. The American Heart Association, American College of Sports Medicine, European Association for Cardiovascular Prevention and Rehabilitation, Canadian Association of Cardiac Rehabilitation, American Association of Cardiovascular and Pulmonary Rehabilitation Guidelines and Scottish Intercollegiate Guidelines endorse moderate- to vigorous-intensity exercise, while Australia, New Zealand, Japan, and the UK favor lower-intensity exercise. ${ }^{6-10}$ Current Australian guidelines recommend 30 minutes or more of low- to moderateintensity physical activity for most people with CHD. For participants with high levels of fitness who aim to return to high-intensity physical activity, the Australian guidelines state that high-intensity training may be offered with their treating doctor's consent. ${ }^{\text {? }}$

The exercise component of CR programs should ensure that the prescription of exercise results in significant improvements in cardiorespiratory fitness and also adequately evaluate changes resulting from participation. This is because, for every one metabolic equivalent (MET) improvement in cardiorespiratory fitness, there is an $8-17 \%$ reduction in all-cause mortality, and cardiorespiratory fitness levels can predict prognosis in patients with known CHD. ${ }^{11-13}$ Prescribing rehabilitative exercise, which increases cardiorespiratory fitness to the greatest extent, could have superior influence in reducing all-cause and cardiovascular mortality.

Benefits of high-intensity interval training (HIIT) in patients with coronary artery disease (CAD) have been investigated since $1981 .{ }^{14}$ Growing evidence is demonstrating superior patient outcomes resulting from HIIT, compared to MICT, in patients with CAD. There have been four systematic reviews reporting on the positive effects (specifically, change in peak oxygen uptake $\left[\mathrm{VO}_{2}\right.$ peak]) of HIIT versus MICT in patients with CAD. ${ }^{15-18}$ All of these concluded that HIIT is superior to MICT in improving aerobic fitness.

In patients with CHD, HIT has been shown to significantly improve $\mathrm{VO}_{2}$ at ventilatory threshold, left ventricular size and function, contractile function, left ventricular diastolic diameter, diastolic volume, posterior wall thickening, fractional shortening and rate pressure product, cardiorespiratory fitness, ejection fraction, and endothelial function to a greater extent than MICT. Therefore, this shows positive outcomes for heart function. In addition, studies have shown HIIT to improve mitochondrial biogenesis, insulin sensitivity ${ }^{19}$ and glucose regulation, ${ }^{20}$ HDL cholesterol, blood pressure, ${ }^{19}$ and deep abdominal adiposity ${ }^{21}$ more than MICT, all of which are important for patients with CHD.

The previously published systematic reviews included between 7 and 10 studies, with participant numbers ranging from 206 to 472 participants. These systematic reviews, however, had methodological limitations including high heterogeneity $\left(I^{2}=83-93 \%\right)^{16,18}$ and lacked sufficient reporting of methods implemented to calculate standard deviations, particularly when no $p$-value was published in individual randomised controlled trial (RCT) publications. ${ }^{15,18}$ Additionally, a fixed-effect analysis ${ }^{17}$ was chosen for statistical analysis, despite variances across trials in methods used (cycle ergometer vs treadmill) to determine peak aerobic capacity. ${ }^{17}$ One of the reviews included non-randomized controlled trials, ${ }^{15}$ and three reviews included trials with CR participants as well as those diagnosed with heart failure. ${ }^{15,16,18}$

Despite the significant research conducted to date, there has been no systematic review and meta-analysis investigating HIIT versus MICT that has analyzed the effect of duration, in weeks, of programs on cardiorespiratory fitness changes. Furthermore, other than adverse events resulting from HIIT and MICT being recorded by Rognmo et $\mathrm{al}^{22}$ across three Norwegian clinics, there has not been an attempt to collate adverse events recorded as a result of HIIT or MICT across all studies.

The aim of this review, therefore, was to undertake a metaanalysis of RCTs within the cardiac population that investigates the overall effect of cardiorespiratory fitness changes resulting from HIIT versus MICT over different durations of interventions and to collate adverse events recorded as a result of both interventions. Our hypothesis was that HIIT would result in greater changes to cardiorespiratory fitness, and this change would be greater with a longer duration of the intervention.

\section{Methods}

A narrative synthesis and meta-analysis was undertaken as detailed in the protocol registered with PROSPERO - an international database of prospectively registered systematic reviews in health and social care (Registration Number CRD42017072093). ${ }^{23}$ A systematic search of all RCTs was done by two authors (AH and VS) at the end of July 2017, in accordance with PRISMA guidelines. ${ }^{24}$ 


\section{Study selection \\ Inclusion criteria}

The inclusion criteria for this systematic review were fulllength research articles published in peer-reviewed academic journals with no limits set on language, date of publication, or gender. Only RCTs up to July 2017 were eligible. Studies comprised participants who were diagnosed with CAD (myocardial infarction [MI], percutaneous intervention [PCI], or coronary artery bypass surgery [CABG]) who engaged in HIIT (eg, $\geq 85 \% \mathrm{VO}_{2}$ peak or $\geq 85 \%$ heart-rate reserve [HRR] or $\geq 90 \%$ heart-rate max [HRM] interspersed with lower level exercise) versus MICT $\left(50-75 \% \mathrm{VO}_{2}\right.$ peak or $50-75 \% \mathrm{HRR}$ or $50-80 \% \mathrm{HRM}$ ) interventions, in an outpatient setting for at least 4 weeks.

The primary outcome used in the meta-analysis was cardiorespiratory fitness $\left(\mathrm{VO}_{2}\right.$ peak or $\mathrm{VO}_{2}$ at anaerobic threshold [AT]) and the assessment must have been conducted before and after the CR intervention. The secondary outcome was adverse events, including minor and major cardiovascular events, and additional adverse events occurring within the intervention period.

\section{Exclusion criteria}

Abstracts, conference presentations or posters, letters to the editor or book chapters, unpublished papers, or retrospective designs were excluded. In addition, studies were excluded if participants were diagnosed with congestive heart failure (ejection fraction $<40 \%$ ) and if HIIT intervention participants did not exercise at $\geq 85 \% \mathrm{VO}_{2}$ peak or equivalent, if the baseline data were not published, or if outcomes other than $\mathrm{VO}_{2}$ peak or anaerobic threshold (such as peak work capacity) were used as primary outcomes.

\section{Literature search}

The following databases - Embase, Medline, CINAHL, SPORTDiscus, and Web of Science - along with reference lists of eligible studies, were systematically searched. Key terms and searches were formulated in consultation with a university librarian. These terms were adapted for each unique database. The search strategy for Embase is available in Supplementary material.

\section{Data extraction}

All data were extracted by the principal investigator and checked for accuracy by a second author. Search results were entered into Endnote, a reference management tool, and duplicates were removed. Abstracts were screened for eligibility, and full-length manuscripts of potential studies were retrieved for further assessment of eligibility. Disagreements regarding eligibility were resolved by consensus, and the selection process was entered into a PRISMA diagram (Figure 1).

For each RCT, the author, year of publication, participant characteristics (age, gender, and diagnosis), and exercise parameters (number of HIIT and MICT participants, length of exercise program, intensity of HIIT and MICT exercise, mode, pre- and post- $\mathrm{VO}_{2}$ peak values, and change in $\mathrm{VO}_{2}$ peak $/ \mathrm{VO}_{2}$ at $\mathrm{AT}$ ) were extracted, if published.

\section{Study quality}

The Physiotherapy Evidence Database Scale (PEDro-Scale) rating was modified to assess and rate the quality of the trials to be included ${ }^{25}$ This tool comprises an 11-item criteria list, which allows rapid identification of studies that are internally valid and is based on the Delphi list developed by Verhagen et al. ${ }^{25}$ The PEDro-Scale assesses how the studies are reported and includes whether subjects were randomly allocated, allotment was concealed, comparable baseline measures of patients were present, if subjects, therapists, and assessors were blinded, whether outcome measures were taken from $>85 \%$ of starting participants, patients received the allocated treatment and included intention to treat, and whether there was statistical comparison. Eligibility criteria, for external validity only, was included, but not used in final rating scores. The nature of HIIT and MICT interventions does not allow for blinding of subjects or of therapists; thus, this was removed in the analysis of quality. Therefore, with these modifications, the maximum total score rating was 8. Two of the authors independently rated the studies (AH and VS). Studies were rated as poor, fair, and good based on the percentage of maximum scores received as described by Kennelly ${ }^{26}$ and Lyons et al. ${ }^{27}$ Studies of good quality received $>61 \%$ of available scores; fair-quality studies received $45.4-61 \%$ of available scores; and poor studies received $<45.4 \%$ of available scores.

\section{Statistical analysis}

A meta-analysis using Review Manager (Version 5.3; The Nordic Cochrane Centre, Copenhagen), to investigate the comparison of $\mathrm{VO}_{2}$ peak changes or $\mathrm{VO}_{2}$ at anaerobic threshold using HIIT versus MICT for those diagnosed with CAD, was carried out. Studies were collated according to the duration of the intervention (up to 6 weeks, 7-12 weeks, and $>12$ weeks).

Effect sizes for continuous variables were calculated as either mean difference or standardized mean differences 


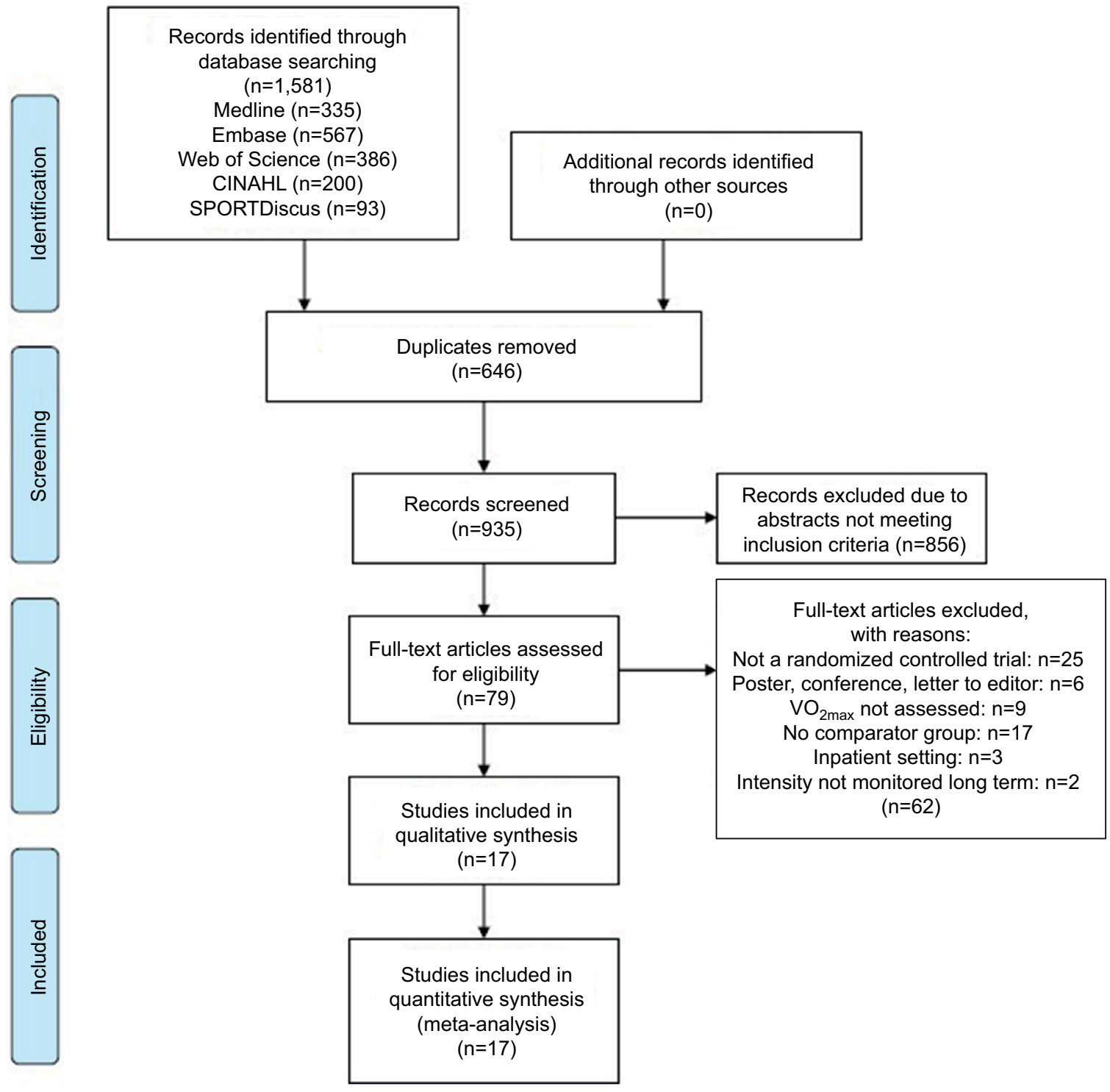

Figure I PRISMA diagram of literature search strategies.

Abbreviation: PRISMA, Preferred Reporting Items for Systematic Reviews and Meta-analysis.

(SMD), in case different methods were used to assess the primary outcome (treadmill vs cycle ergometer), each with a 95\% confidence interval (CI). The effect of treatment was calculated as the difference between intervention (HIIT or MICT) from baseline to end of follow-up. For each outcome, variance was estimated on the basis of standard deviation of the mean difference. When standard deviation was not available, we used the $p$-value between groups, then within groups, or the highest calculated standard deviation if no $p$-values were available, as recommended by the Cochrane Handbook for Systematic Reviews of Interventions. ${ }^{28}$ If the $p$-value was reported as $<0.05$, a conservative approach was used and 0.05 was used in the calculations. A random effects model and standardized means model was used to account for differences in methodology of included studies (both in assessment of cardiorespiratory fitness and variations in interventional equipment and protocols) as well as durations of intervention to ensure a conservative estimate was calculated.

An overall forest plot was constructed which included all studies. Heterogeneity was assessed using $I^{2}$ and was considered significant at $p<0.1$. Heterogeneity was considered minimal if $I^{2}$ fell between $0 \%$ and $30 \%$, moderate if $30-50 \%$, substantial if 50-90\%, and considerable if $>90 \% .{ }^{29}$ Publication bias was analyzed using a funnel plot derived in Review Manager version 5.3..$^{30}$

A sensitivity analysis was conducted to investigate possible effects of certain studies on heterogeneity and overall effect. 


\section{Results}

The initial search resulted in 1,581 references. After duplicates were removed, the titles of 935 studies and abstracts were reviewed. Following a screening of potential records, 79 articles were reviewed for eligibility and reference lists screened. Seventeen RCTs were identified that met eligibility criteria for the systematic review and meta-analysis (Figure 1).

\section{Study characteristics}

Seventeen studies were included in the narrative analysis and all were published in English. ${ }^{31-47}$ The RCTs were conducted in the US ( $n=2)$, Belgium ( $\mathrm{n}=1)$, Brazil $(\mathrm{n}=4)$, Canada $(n=3)$, Germany $(n=1)$, Norway $(n=4)$, South Korea $(n=1)$, and Spain $(n=1)$. The total number of participants analyzed across all studies was 953 participants (465 for HIIT and 488 for MICT). Not all studies reported the breakdown of gender; however, for those which did, there were 5.5 times more males (661) reported than females (119). There were 123 patients reported as having CAD, $633 \mathrm{MI}, 477 \mathrm{PCI}$, and $361 \mathrm{CABG} /$ myocardial revascularizations. The age range of participants was 52-76 years, with 10 studies reporting mean ages $<60$ years and seven studies reporting mean ages $>60$ years. Individual patient characteristics for each study can be seen in Table 1 .

Intervention duration ranged from 4 weeks to 12 months, with four studies reporting data for $0-6$ weeks, ${ }^{35,42,44,46} 11$ studies reporting data for $7-12$ weeks, $, 32,34,36-40,42,43,45,47$ and five studies reporting data for $>12$ weeks. ${ }^{31,33,35,41,43}$ Four studies had data that fit across subgroups and results recorded separately for each different duration ${ }^{31,35,42,43}$ (Table 2).

Sixteen studies reported on the frequency of training (days/week) used during the intervention. Of these, nine studies conducted the intervention 3 days/week, ${ }^{31,32,38,40-42,44,45,47}$ four studies for 2 days/week, ${ }^{33,37,39,43}$ and two studies for 5 days/week. ${ }^{35,36}$ One study ran sessions four times a day ${ }^{46}$ and another did not report frequency ${ }^{36}$ (Table 2).

Of the studies that reported the mode of exercise used during training sessions, nine studies primarily utilized a treadmill, $, 32,36,35,37,38,40,41,44,47$ four primarily used cycle ergometers, ${ }^{39,42,43,45}$ one described the intervention as aerobic exercise, ${ }^{36}$ another used a combination of a stair climber, treadmill, and arm/leg cycle ergometer, ${ }^{33}$ one described the intervention as multimodal exercise ${ }^{46}$ and another used a combination of walking/jogging or cycling ${ }^{31}$ (Table 2).

All studies conducted exercise within the intensity guidelines (HIIT $\geq 85 \% \mathrm{VO}_{2}$ peak or $\geq 85 \%$ heart rate reserve [HRR] or $\geq 90 \%$ heart rate max [HRM] interspersed with lower level exercise and MICT $\left[50-75 \% \mathrm{VO}_{2}\right.$ peak or $50-75 \%$ HRR or 50-80\% HRM]).

The PEDro-Scale was used to analyze study quality. Seventeen studies were scored by two authors (AH and VS) independently, and discrepancies were discussed and resolved. Of the 17 studies, 13 (76\%) were of good quality, three $(18 \%)$ were of fair quality, and one $(6 \%)$ was of poor quality (Table 3).

Studies were separated into three groups depending upon duration (0-6,7-12, and $>12$ weeks), and a metaanalysis was conducted to analyze $\mathrm{VO}_{2}$ peak changes or $\mathrm{VO}_{2}$ at anaerobic threshold. In addition, studies that reported results across two different time frames were separated in to "a" and "b" subgroups. . $^{31,35,42,43}$ The forest plots for changes in $\mathrm{VO}_{2}$ peak or $\mathrm{VO}_{2}$ at anaerobic threshold between HIIT and MICT interventions with subgroups based upon duration are seen in Figure 2. The meta-analysis identified that, of the 17 studies, 16 significantly $(p<0.05)$ favored HIIT. ${ }^{31-45,47}$ One favored MICT; $;{ }^{46}$ however, the results were not significant in our meta-analysis ( $p=0.3758$ ). HIIT was significantly superior to MICT in improving $\mathrm{VO}_{2}$ peak (SMD $0.34 \mathrm{~mL} / \mathrm{kg} / \mathrm{min} ; 95 \%$ CI [0.2-0.48]; $p<0.00001$; $I^{2}=28 \%$ ). For studies of up to 6-week duration, HIIT was shown to improve $\mathrm{VO}_{2}$ peak more than MICT (SMD 0.19 $\mathrm{mL} / \mathrm{kg} / \mathrm{min} ; 95 \%$ CI $[-0.16$ to 0.54$] ; p=0.3 ; I^{2}=45 \%$ ); however, this was not significant. For interventions of 7-12 weeks, HIIT was found to be significantly superior to MICT in improving $\mathrm{VO}_{2}$ peak (SMD $0.43 \mathrm{~mL} / \mathrm{kg} / \mathrm{min}$; $95 \%$ CI [0.23-0.62], $\left.p<0.0001 ; I^{2}=15 \%\right)$. For studies of $>12$-weeks duration, HIIT was significantly superior to MICT in improving $\mathrm{VO}_{2}$ peak (SMD $0.32 \mathrm{~mL} / \mathrm{kg} / \mathrm{min} ; 95 \%$ CI $[0.07-0.56] ; p=0.01 ; I^{2}=35 \%$ ).

Figure 3 depicts a funnel plot for publication bias that suggests this to be unlikely.

Although the majority of trials $(13 / 17 ; 76 \%)$ commented on adverse events resulting from exercise interventions, ${ }^{32-37,39-42,44-46}$ no studies stated the use of a specific protocol to collect adverse events. Of those studies that reported events, no deaths or cardiac-related events requiring hospitalization occurred in either intervention group during training. One study (7\%) reported that three cardiac events occurred in the MICT training group. One of these was 24 hours after exercise, and two occurred after the intervention was completed and during the post-intervention exercise test. ${ }^{42}$ Although one study (7\%) reported incidences of angina resulting in drop out occurring in both groups, specific details were not reported. ${ }^{37}$ Of the 13 studies reporting adverse events, three studies (23\%) reported additional 
Table I Study characteristics

\begin{tabular}{|c|c|c|c|}
\hline$\overline{\text { Study }}$ & Age (years) & $\begin{array}{l}\text { Gender } \\
\text { male/female }\end{array}$ & $\begin{array}{l}\text { Diagnosis } \\
\text { MI, CAD, PCI, } \\
\text { CABG }\end{array}$ \\
\hline $\begin{array}{l}\text { Jensen } \\
\text { et } \mathrm{al}^{31}\end{array}$ & $\begin{array}{l}53 \pm 0.6 \text { (total) } \\
53.1 \pm 0.9 \text { HIIT } \\
54.6 \pm 0.9 \text { MICT }\end{array}$ & $199 / 0$ & MI: II7 \\
\hline $\begin{array}{l}\text { Rognmo } \\
\text { et } \mathrm{al}^{32}\end{array}$ & $\begin{array}{l}62.9 \pm I I .2 \mathrm{HIIT} \\
61.2 \pm 7.3 \mathrm{MCT}\end{array}$ & $\begin{array}{l}\text { 6/2 HIIT } \\
\text { 8/I MICT }\end{array}$ & $\begin{array}{l}\text { CAD: I } \\
\text { MI: } 8 \\
\text { PCI: } 3 \\
\text { CABG: } 5\end{array}$ \\
\hline $\begin{array}{l}\text { Warburton } \\
\text { et } \mathrm{al}^{33}\end{array}$ & $\begin{array}{l}56 \pm 7 \text { (total) } \\
55 \pm 7 \text { HIIT } \\
57 \pm 8 \text { MICT }\end{array}$ & $14 / 0$ & $\begin{array}{l}\text { MI: } 5 \\
\text { PCI: } 6 \\
\text { CABG: } 6\end{array}$ \\
\hline $\begin{array}{l}\text { Amundsen } \\
\text { et } \mathrm{al}^{34}\end{array}$ & $\begin{array}{l}63 \pm 11 \text { HIIT } \\
61 \pm 7 \text { MICT }\end{array}$ & $\begin{array}{l}\text { 6/2 HIIT } \\
8 / I \text { MICT }\end{array}$ & $\begin{array}{l}\text { MI: } 8 \\
\text { PCI: } 3 \\
\text { CABG: } 6\end{array}$ \\
\hline $\begin{array}{l}\text { Moholdt } \\
\text { et al }\left.\right|^{35}\end{array}$ & $\begin{array}{l}60.2 \pm-6.9 \mathrm{HIIT} \\
62 \pm 7.6 \mathrm{MICT}\end{array}$ & $\begin{array}{l}\text { 24/4 HIIT } \\
\text { 24/7 MICT }\end{array}$ & $\begin{array}{l}\text { MI: } 56 \text { (4 weeks) } \\
\quad 48 \text { (6 months) }\end{array}$ \\
\hline $\begin{array}{l}\text { Benetti } \\
\text { et } \mathrm{al}^{36}\end{array}$ & $57.7 \pm 6.1$ (total) & $87 / 0$ & $\begin{array}{l}\text { MI: } 25 \\
\text { PTCA: } 37 \\
\text { CABG: } 34\end{array}$ \\
\hline $\begin{array}{l}\text { Moholdt } \\
\text { et } \mathrm{al}^{37}\end{array}$ & $\begin{array}{l}57.4 \pm 9.5 \text { (total) } \\
56.7 \pm 10.4 \text { HIIT } \\
57.7 \pm 9.3 \mathrm{MICT}\end{array}$ & $74 / 15$ & $\begin{array}{l}\text { MI: } 89 \\
\text { PCl: } 70\end{array}$ \\
\hline Rocco et $\mathrm{a}^{38}$ & $\begin{array}{l}59.7 \pm 1.7 \text { (total) } \\
56.5 \pm 3 \text { HIIT } \\
62.5 \pm 2 \text { MICT }\end{array}$ & $28 / 9$ & $\begin{array}{l}\text { CAD: } 20 \\
\text { MI: } 17\end{array}$ \\
\hline Currie et $\mathrm{al}^{39}$ & $\begin{array}{l}62 \pm I I \text { HIIT } \\
68 \pm 8 \text { MICT }\end{array}$ & $\begin{array}{l}\text { 23/3; } 3 \text { participants } \\
\text { excluded unclear } \\
\text { as to gender }\end{array}$ & $\begin{array}{l}\text { MI: I3 } \\
\text { PCI: I4 } \\
\text { CABG: } 7\end{array}$ \\
\hline $\begin{array}{l}\text { Keteyian } \\
\text { et } \mathrm{al}^{40}\end{array}$ & $\begin{array}{l}60 \pm \mathrm{HIIT} \\
58 \pm 9 \text { MICT }\end{array}$ & $23 / 5$ & $\begin{array}{l}\text { MI: } 17 \\
\text { PCI: } 19 \\
\text { CABG: } 7\end{array}$ \\
\hline $\begin{array}{l}\text { Cardozo } \\
\text { et } \mathrm{a}^{41}\end{array}$ & $\begin{array}{l}56 \pm 12 \text { HIIT } \\
62 \pm 12 \text { MICT }\end{array}$ & $\begin{array}{l}\text { I4/9 HIIT } \\
\text { I6/8 MICT }\end{array}$ & $\begin{array}{l}\text { CAD: } 102 \\
\text { MI: } 105 \\
\text { PCI: I75 } \\
\text { Myocardial } \\
\text { revascularisation: } \\
\text { I32 }\end{array}$ \\
\hline $\begin{array}{l}\text { Conraads } \\
\text { et } \mathrm{al}^{42}\end{array}$ & $\begin{array}{l}58.4 \pm 9.1 \text { (total) } \\
57 \pm 8.8 \text { HIIT } \\
59.9 \pm 9.2 \text { MICT }\end{array}$ & $\begin{array}{l}\text { 180/20 } \\
91 / 9 \text { HIIT } \\
89 / 1 \text { I MICT }\end{array}$ & $\begin{array}{l}\text { MI: II5 } \\
\text { PCI: } 25 \\
\text { CABG: } 60\end{array}$ \\
\hline $\begin{array}{l}\text { Currie } \\
\text { et } \mathrm{al}^{43}\end{array}$ & $\begin{array}{l}63 \pm 8 \text { HIIT } \\
66 \pm 8 \text { MICT }\end{array}$ & $\begin{array}{l}\text { I8/I } \\
9 \text { HIIT } \\
\text { I0/I MICT }\end{array}$ & $\begin{array}{l}\text { MI: I2 } \\
\text { PCI: II } \\
\text { CABG: } 7\end{array}$ \\
\hline $\begin{array}{l}\text { Kim } \\
\text { et al }{ }^{44}\end{array}$ & $\begin{array}{l}57 \pm I I .58 \mathrm{HIIT} \\
60.2 \pm 13.64 \mathrm{MICT}\end{array}$ & $\begin{array}{l}22 / 6 \\
12 / 2 \text { HIIT } \\
\text { 10/4 MICT }\end{array}$ & MI with PCl: 28 \\
\hline Jaureguizar & $58 \pm$ I I HIIT & 28/8 HIIT & MI: 46 \\
\hline et $\mathrm{al}^{45}$ & 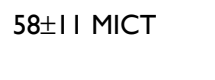 & 33/3 MICT & $\begin{array}{l}\text { PCI: } 47 \\
\text { CABG: } 13\end{array}$ \\
\hline Möbius- & $64.4 \pm 7.7$ (total) & I4/6 HIIT & Ml: 13 \\
\hline Winkler et $\mathrm{al}^{46}$ & $\begin{array}{l}61.4 \pm 8.7 \mathrm{HIIT} \\
66 \pm 5.9 \mathrm{MICT}\end{array}$ & 16/2 MICT & $\begin{array}{l}\text { PCl: } 30 \\
\text { CABG: } 2\end{array}$ \\
\hline Prado et $\mathrm{al}^{47}$ & $\begin{array}{l}59.3 \pm 1.8 \text { (total) } \\
56.5 \pm 2.7 \text { HIIT } \\
61.3 \pm 2.7 \text { MICT }\end{array}$ & $\begin{array}{l}\text { 28/7 } \\
\text { I 4/3 HIIT } \\
\text { I 4/4 MICT }\end{array}$ & $\begin{array}{l}\text { MI: } 15 \\
\text { PCI: } 9 \\
\text { CABG: } 26\end{array}$ \\
\hline
\end{tabular}

Abbreviations: $\mathrm{Ml}$, myocardial infarct; $\mathrm{CAD}$, coronary artery disease; $\mathrm{PCl}$, percutaneous coronary intervention; CABG, coronary artery bypass graft surgery; HIIT, high-intensity interval training; MICT, moderate-intensity continuous training. adverse events for the HIIT intervention. These included ankle fracture,${ }^{32}$ leg or hip pain, bronchitis, ${ }^{35}$ gastroenteritis, pancreatitis, and intermittent claudication. ${ }^{37}$ Five studies (38\%) reported additional adverse events in the MICT intervention branch. These included knee injury, ${ }^{32}$ pericardial effusion, ${ }^{35}$ gastrointestinal bleed, bronchitis, knee surgery, lower back pain and psychiatric disease, ${ }^{37}$ musculoskeletal injury unrelated to training, ${ }^{39}$ and limiting leg pain. ${ }^{40}$ In addition, two studies (14\%) reported additional adverse events; however, they did not describe to which intervention group the participants had belonged. ${ }^{36,36}$ These included physical impairment not attributable to cardiovascular disease, ${ }^{36}$ unstable angina, and joint problems. ${ }^{36}$ Table 4 depicts adverse events reported.

Less than half the studies $(6 / 17 ; 35 \%)$ reported dropout rates by intervention group. Of those that did, 39 participants were reported to drop out of the HIIT group and 42 out of the MICT group.

A sensitivity analysis was conducted within each subgroup. For the 0-6 weeks-duration studies, heterogeneity dropped to $0 \%$ when $\mathrm{Kim}$ et $\mathrm{al}^{44}$ was removed, and total heterogeneity was similar $(26 \%)$. For studies of $7-12$ weeks duration, removal of results from Conraads et $\mathrm{al}^{42}$ reduced the heterogeneity to $6 \%$; however, it increased the total heterogeneity to $31 \%$. Removal of Rognmo et $\mathrm{al}^{32}$ dropped heterogeneity to $0 \%$ and the overall heterogeneity to $22 \%$. Both these studies were of good quality (PEDROScale 6).

In the subgroup which included studies of $>12$-week duration, removing the $3-$ month data from Jensen et $\mathrm{al}^{31}$ dropped the heterogeneity to $0 \%$ and overall heterogeneity to $17 \%$. The study by Jensen et $\mathrm{al}^{31}$ was of good quality (Pedro score 7). Moreover, Jensen et $\mathrm{al}^{31}$ had the lowest standard deviation variation and favored HIIT; ${ }^{31}$ however, it included participants who had an ejection fraction $<50 \%$. The exact measures were not recorded. As there was no mention of participants having been diagnosed with heart failure, we assumed their ejection fraction was $>40 \%$ and included this study in the meta-analysis.

Rocco et $\mathrm{al}^{38}$ and Prado et $\mathrm{al}^{47}$ appear to be the same study with reported mean changes, being identical and with the first three authors being the same. However, Rocco et $\mathrm{al}^{38}$ had two more participants and, therefore, both studies needed to be included in the meta-analysis. When both studies were removed, the heterogeneity in the subgroup dropped to $8 \%$; however, the overall heterogeneity then increased to $32 \%$. The overall effect remained the same throughout all sensitivity analyses, favoring HIIT. 


\section{Discussion}

The main aim of this systematic review and meta-analysis was to ascertain whether HIIT or MICT resulted in greater cardiorespiratory fitness gains for participants with CAD who did not have a diagnosis of heart failure. Furthermore, we aimed to gauge whether the duration of interventions had an effect on the results. Our review and meta-analysis supported our hypothesis that HIIT improves cardiorespiratory fitness to a greater extent than MICT. Interventions of $>12$ weeks did not show larger gains in cardiorespiratory fitness from continued HIIT training, as was expected. In addition, programs of $\leq 6$ weeks did not result in significant changes.

Our findings that HIIT improved cardiorespiratory fitness significantly more than MICT is in agreement with reports from previous meta-analyses. Elliot et a ${ }^{17}$ found a mean difference of $1.53 \mathrm{~mL} / \mathrm{kg} / \mathrm{min}$ (95\% CI $0.84-2.23 ; p=0.0001$ ) increase in cardiorespiratory fitness attributed to HIIT; Pattyn et $\mathrm{al}^{16}$ found a mean difference of $1.6 \mathrm{~mL} / \mathrm{kg} / \mathrm{min}(95 \%$ CI $0.18-3.03 ; p=0.03)$ increase in cardiorespiratory fitness attributed to HIIT; and Liou et a ${ }^{18}$ found a mean difference of $1.78 \mathrm{~mL} / \mathrm{kg} / \mathrm{min}(95 \% \mathrm{CI} 0.45-3.11, p=0.009)$. It is important to highlight that we decided to use SMD, instead of $\mathrm{MD}$, to account for differences in measurement procedures and interventions $(0.34 \mathrm{~mL} / \mathrm{kg} / \mathrm{min} ; 95 \%$ CI [0.2-0.48]; $p<0.00001 ; I^{2}=28 \%$ ). Had we used MD, our findings would be similar to those of previously reported reviews $(1.15 ; 95 \%$ CI $0.76-1.55) ; p<0.00001$ and the heterogeneity would have dropped to $13 \%$.

To the best of the authors' knowledge, our systematic review has included the most number of RCTs and participants to date. Our study confirmed results of previous systematic reviews that HIIT improves cardiorespiratory fitness to a larger extent than MICT. Our findings that HIIT is superior to MICT in improving aerobic capacity are likely to be an underestimation of the true differences between groups. This is supported by the methodological decisions favoring the use of a conservative approach in the metaanalysis (by choosing random effects and SMDs) and using the highest calculated standard deviation for studies where no information was published to allow standard deviation calculations.

The overall heterogeneity in our meta-analysis was minimal (28\%). Test for subgroup differences revealed $0 \%$ heterogeneity. With respect to duration, all time frames of interventions favored HIIT; however, only durations $>6$ weeks were found to be significant. Although studies that were of $<6$ weeks duration had moderate heterogeneity ( $45 \%$ ), and one study in this group favored MICT, this was not significant. ${ }^{46}$
It appears that undertaking HIIT for 7-12 week duration elicited the largest SMD in cardiorespiratory fitness, with studies of greater duration eliciting slightly less overall improvements. This may have implications to delivery length of CR service, where programs of $<7$ weeks or $>12$ weeks may be suboptimal when implementing HIIT. We did not include a study which investigated the longer term benefits ( 1 year post intervention) of HIIT versus MICT as it did not report that the intensity of exercise was monitored throughout the entire study. ${ }^{48}$ The authors, however, did conclude that cardiorespiratory fitness levels were maintained in both groups. ${ }^{48}$ Based upon the sensitivity analysis, although the results suggest that interventions that were conducted five times a week resulted in greater gains of cardiorespiratory fitness favoring HIIT, the analysis only included two studies and may not be practical to implement.

The secondary outcome of this study was to investigate adverse events reported within RCTs implementing HIIT and MICT in the cardiac population. There was only one study that reported any cardiac-related incidences (angina requiring withdrawal), and this occurred in both intervention groups. ${ }^{37}$ There were only a few studies reporting additional adverse effects (primarily, musculoskeletal and digestive issues), with more of these events occurring with MICT.

Our investigation which reported no deaths or cardiacrelated events requiring hospitalization in either the HIIT or MICT intervention branches supports the conclusion made by Rognmo et al that the risk of adverse events was low in both modes of rehabilitative exercise. ${ }^{22}$ Rognmo et al conducted a retrospective analysis of 4,846 patients with cardiovascular disease, which analyzed 175,820 hours of CR exercise training for rates of adverse events. They found one fatal event was reported per 129,456 hours of MICT and two non-fatal events per 23,182 hours of HIIT; therefore, the authors recommended the use of HIIT in CR for people with $\mathrm{CAD}$ due to the significant cardiovascular adaptations gained from its use. ${ }^{22}$

There is conflicting evidence in the literature concerning dropout rates with both exercise methods. Previous research suggests that HIIT would not be adopted, or maintained, by participants because they would not find this type of extreme exercise enjoyable and would, therefore, not be a viable public health strategy ${ }^{49}$ However, additional research has found HIIT to have a more positive affect than MICT. ${ }^{50-52}$ Although our review reported more participants dropped out of MICT, the reasons for dropouts were not well reported in the RCTs. 
Table 2 Exercise parameters

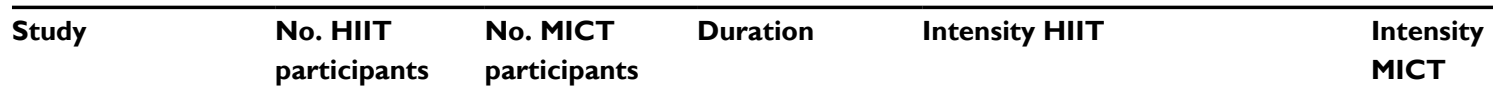

\begin{tabular}{|c|c|c|c|c|c|}
\hline Jensen et $\mathrm{al}^{31}$ & 108 & 91 & $\begin{array}{l}\text { 6-12 months } \\
3 \text { days/week }\end{array}$ & Progressed from $50-85 \% \mathrm{VO}_{2}$ peak & Not recorded \\
\hline
\end{tabular}

\begin{tabular}{|c|c|c|c|c|c|}
\hline Rognmo et $\mathrm{al}^{32}$ & 8 & 9 & $\begin{array}{l}10 \text { weeks } \\
3 \text { days/week }\end{array}$ & $\begin{array}{l}5 \text { minutes warm up } 50-60 \% \mathrm{VO}_{2} \\
\text { peak } \\
\text { (65-75\% HR peak) } \\
4 \times 4 \text { minutes: } \\
4 \text { minutes @ 80-90\% } \mathrm{VO}_{2} \text { peak } \\
\text { (85-95\% } \mathrm{HR} \text { peak): } 3 \text { minutes @ } \\
50-60 \% \mathrm{VO}_{2} \text { peak } \\
3 \text { minutes cool down } \\
50-60 \% \mathrm{VO}_{2} \text { peak }\end{array}$ & $\begin{array}{l}50-60 \% \mathrm{VO}_{2} \text { peak } \\
(65-75 \% \mathrm{HR} \text { peak })\end{array}$ \\
\hline Warburton et $\mathrm{al}^{33}$ & 7 & 7 & $\begin{array}{l}16 \text { weeks } \\
2 \text { days/week }\end{array}$ & $\begin{array}{l}2 \text { minutes } 85-95 \% \mathrm{HR} / \mathrm{VO}_{2} \text { reserve } \\
\text { interspersed with } 2 \text { minutes } \\
\text { recovery @ 35-45\% } \mathrm{HR} / \mathrm{VO}_{2} \\
\text { reserve }\end{array}$ & $60 \% \mathrm{HR} / \mathrm{VO}_{2}$ reserve \\
\hline Amundsen et $\mathrm{al}^{34}$ & 8 & 9 & 10 weeks & $80-90 \%$ peak $\mathrm{O}_{2}$ uptake & $50-60 \%$ peak $\mathrm{O}_{2}$ uptake \\
\hline Moholdt et $\mathrm{al}^{35}$ & 23 & 25 & $\begin{array}{l}4 \text { weeks } \\
5 \text { days/week }\end{array}$ & $\begin{array}{l}\text { HIIT 90\% max HR interspersed with } \\
3 \text { minutes@ } 0 \% \max \text { HR }\end{array}$ & MICT: $70 \% \max \mathrm{HR}$ \\
\hline Benetti et $\mathrm{al}^{36}$ & 29 & 29 & $\begin{array}{l}12 \text { weeks } \\
5 \text { days/week }\end{array}$ & $85 \% \max H R$ & $75 \% \max H R$ \\
\hline Moholdt et $\mathrm{al}^{37}$ & 30 & 59 & $\begin{array}{l}\text { I } 2 \text { weeks } \\
2 \text { days/week } \\
\text { plus I day/week } \\
\text { home }\end{array}$ & $\begin{array}{l}\text { Total } 38 \text { minutes } \\
4 \text { minutes } \times 4 ; 85-95 \% \text { MHR } \\
3 \text { minutes } 70 \% \text { MHR } \\
8 \text { minutes warm up } \\
5 \text { minutes cool down }\end{array}$ & $\begin{array}{l}\text { Periodically encouraged } \\
\text { to do vigorous exercises }\end{array}$ \\
\hline Rocco et $\mathrm{al}^{38}$ & 17 & 20 & $\begin{array}{l}12 \text { weeks } \\
3 \text { days/week }\end{array}$ & Respiratory compensation point & VT \\
\hline Currie et $\mathrm{al}^{39}$ & II & 10 & $\begin{array}{l}12 \text { weeks } \\
2 \text { days/week }\end{array}$ & $\begin{array}{l}89 \% \text { peak power } \\
\text { Range } 80-104 \%\end{array}$ & $\begin{array}{l}58 \% \text { peak power } \\
\text { Range } 51-65 \%\end{array}$ \\
\hline
\end{tabular}




\begin{tabular}{|c|c|c|c|c|c|c|}
\hline \multirow[t]{2}{*}{$\begin{array}{l}\text { Protocol } \\
\text { HIIT }\end{array}$} & \multirow[t]{2}{*}{$\begin{array}{l}\text { Protocol } \\
\text { MICT }\end{array}$} & \multicolumn{2}{|l|}{$\begin{array}{l}\text { HIIT } \\
\mathrm{mL} / \mathrm{kg} / \mathrm{min} \\
(\mathrm{mean} \pm \mathrm{SD})\end{array}$} & \multicolumn{2}{|c|}{$\begin{array}{l}\text { MICT } \\
\mathrm{mL} / \mathrm{kg} / \mathrm{min} \\
(\mathrm{mean} \pm \mathrm{SD})\end{array}$} & \multirow{2}{*}{$\begin{array}{l}\text { Change in } \\
\mathrm{V}_{2 \text { peak }} \\
\mathrm{mL} / \mathrm{kg} / \mathrm{min} \\
\text { (mean } \pm \mathrm{SD} \text { ) }\end{array}$} \\
\hline & & $\mathrm{VO}_{2 \text { peak }}$ Pre & $\mathrm{VO}_{2 \text { peak }}$ Post & $\mathrm{VO}_{2 \text { peak }}$ Pre & $V_{2 \text { peak }}$ Post & \\
\hline $\begin{array}{l}\text { Walking /jogging and/or } \\
\text { cycle ergometer }\end{array}$ & $\begin{array}{l}\text { Walking/jogging and/or } \\
\text { cycle ergometer }\end{array}$ & $25.3 \pm 4.9$ & $\begin{array}{l}6 \text { months: } \\
27.2 \pm 5.6\end{array}$ & $24.3 \pm 4.8$ & $\begin{array}{l}6 \text { months: } \\
26.1 \pm 4.4\end{array}$ & 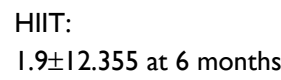 \\
\hline 45 minutes & 45 minutes & & $\begin{array}{l}\text { I2 months: } \\
28.5 \pm 5.9\end{array}$ & & $\begin{array}{l}12 \text { months: } \\
26.6 \pm 5.7\end{array}$ & $\begin{array}{l}3.2 \pm 1.893 \text { at } 12 \text { months } \\
\text { MICT: } \\
1.8 \pm 12.355 \text { at } 6 \text { months } \\
2.3 \pm 1.893 \text { at } 12 \text { months }\end{array}$ \\
\hline $\begin{array}{l}\text { Uphill treadmill walking } \\
33 \text { minutes }\end{array}$ & $\begin{array}{l}\text { Continuous } \\
\text { uphill treadmill walking } \\
41 \text { minutes }\end{array}$ & $31.8 \pm 9.3$ & $37.8 \pm 12.4$ & $32.1 \pm 5.3$ & $34.8 \pm 5.7$ & $\begin{array}{l}\text { HIIT: } \\
6 \pm 2.342 \\
\text { MICT: } \\
2.7 \pm 2.342\end{array}$ \\
\hline
\end{tabular}

\begin{tabular}{|c|c|c|c|c|c|c|}
\hline $\begin{array}{l}\text { I0 minutes each of } \\
\text { treadmill, stair climber, } \\
\text { arm/leg cycle }\end{array}$ & $\begin{array}{l}\text { I } 0 \text { minutes each of } \\
\text { treadmill, stair climber, } \\
\text { arm/leg cycle }\end{array}$ & $\begin{array}{l}\mathrm{VO}_{2} \text { peak at } \\
\text { anaerobic } \\
\text { threshold }\end{array}$ & $\begin{array}{l}\mathrm{VO}_{2} \text { peak at } \\
\text { anaerobic } \\
\text { threshold }\end{array}$ & $\begin{array}{l}\mathrm{VO}_{2} \text { peak at } \\
\text { anaerobic } \\
\text { threshold }\end{array}$ & $\begin{array}{l}\mathrm{VO}_{2} \text { peak at } \\
\text { anaerobic } \\
\text { threshold }\end{array}$ & $\begin{array}{l}\text { HIIT: } 7 \pm 7.565 \\
\text { MICT: } 2 \pm 2.1625\end{array}$ \\
\hline $\begin{array}{l}3 \text { additional training days } \\
@ 60-70 \text { HRR } \\
30 \text { minutes }\end{array}$ & $\begin{array}{l}3 \text { additional training } \\
\text { days @ 60-70 HRR } \\
30 \text { minutes }\end{array}$ & $22 \pm 4$ & $29 \pm 8$ & $2 \mathrm{I} \pm 3$ & $23 \pm 2$ & \\
\hline $\begin{array}{l}\text { Uphill treadmill } \\
4 \times 4 \text {-minutes interval } \\
3 \text { minutes }\end{array}$ & $\begin{array}{l}\text { Uphill treadmill } \\
4 I \text { minutes }\end{array}$ & $32 \pm 19$ & $37 \pm 27$ & $3 I \pm 9$ & $35 \pm 11$ & $\begin{array}{l}\text { HIIT: } 5 \pm 0.698 \\
\text { MICT: } 4 \pm 0.698\end{array}$ \\
\hline $\begin{array}{l}8 \text { minutes warm up } \\
4 \times 4 \text {-minute intervals } \\
5 \text { minutes cool down } \\
\text { treadmill }\end{array}$ & $\begin{array}{l}\text { Continuous } \\
\text { treadmill } \\
46 \text { minutes }\end{array}$ & $27.1 \pm 4.5$ & $\begin{array}{l}4 \text { weeks } \\
30.4 \pm 5.5 \\
6 \text { months } \\
32.2 \pm 7\end{array}$ & $26.2 \pm 5.2$ & $\begin{array}{l}4 \text { weeks } \\
28.5 \pm 5.6 \\
6 \text { months } \\
29.5 \pm 5.7\end{array}$ & $\begin{array}{l}\text { HIIT: } 4 \text { weeks } 3.3 \pm 4.7328 \\
6 \text { months } \\
5 . I \pm 2.9475 \\
\text { MICT: } 4 \text { weeks } 2.3 \pm 3.5 \mathrm{I} 23 \\
6 \text { months } \\
3.3 \pm 2.9475\end{array}$ \\
\hline $\begin{array}{l}\text { Aerobic exercise } \\
45 \text { minutes } \\
+15 \text { minutes stretching }\end{array}$ & $\begin{array}{l}\text { Aerobic exercise } \\
45 \text { minutes } \\
+15 \text { minutes stretching }\end{array}$ & $29.2 \pm 2.2$ & $41.6 \pm 3.9$ & $32 \pm 5.3$ & $37.1 \pm 3.9$ & $\begin{array}{l}\text { HIIT: } 12.4 \\
\pm I 2.355 \\
\text { MICT: } 5 . I \pm I 2.355\end{array}$ \\
\hline Treadmill & $\begin{array}{l}10 \text { minutes warm up } \\
\text { Walk/jog/squat/lunge } \\
35 \text { minutes } \\
5 \text { minutes cool down } \\
\text { Stretching/relax } \\
\text { Total } 60 \text { minutes }\end{array}$ & $31.6 \pm 5.8$ & $36.2 \pm 8.6$ & $32.2 \pm 6.7$ & $34.7 \pm 7.9$ & $\begin{array}{l}\text { HIIT: } 4.6 \pm 4.2 \\
\text { MICT: } 2.4 \pm 3.2\end{array}$ \\
\hline $\begin{array}{l}5 \text { minutes warm up and } \\
\text { cool down } \\
7 \times 3 \text { minutes } \mathrm{RCP} \text { and } 7 \times 3 \\
\text { minutes VT } \\
\text { Treadmill } \\
42 \text { minutes }\end{array}$ & $\begin{array}{l}5 \text { minutes warm up and } \\
\text { cool down } \\
\text { Treadmill } \\
50 \text { minutes }\end{array}$ & $17.9 \pm 1$ & $22.3 \pm 1.1$ & $18 \pm 1.2$ & $22.2 \pm 1.3$ & $\begin{array}{l}\text { HIIT: } 4.4 \pm 8.5578 \\
\text { MICT: } 4.2 \pm 8.974 \text { I }\end{array}$ \\
\hline $\begin{array}{l}\text { I0XI minutes intervals } \\
\text { at } 89 \% \text { peak power } \\
\text { output interspersed with } \\
\text { I minute at } 10 \% \text { peak } \\
\text { power output cycling }\end{array}$ & $\begin{array}{l}\text { Continuous cycling } \\
30-50 \text { minutes }\end{array}$ & $19.8 \pm 3.7$ & $24.5 \pm 4.5$ & $18.7 \pm 5.7$ & $22.3 \pm 6.1$ & $\begin{array}{l}\text { HIIT: } 4.7 \pm 3.398 \\
\text { MICT: } 3.6 \pm 2.6\end{array}$ \\
\hline
\end{tabular}

(Continued) 
Table 2 (Continued)

\begin{tabular}{|c|c|c|c|c|c|}
\hline Study & $\begin{array}{l}\text { No. HIIT } \\
\text { participants }\end{array}$ & $\begin{array}{l}\text { No. MICT } \\
\text { participants }\end{array}$ & Duration & Intensity HIIT & $\begin{array}{l}\text { Intensity } \\
\text { MICT }\end{array}$ \\
\hline Keteyian et $\mathrm{al}^{40}$ & 15 & 13 & $\begin{array}{l}\text { I-2 weeks } \\
\text { MICT then } \\
\text { I0-week trial } \\
3 \text { days/week }\end{array}$ & 80-90\% HRR & $60-80 \%$ HRR \\
\hline Cardozo et $\mathrm{al}^{4 \mathrm{I}}$ & 23 & $\begin{array}{l}24 \\
24 \\
\text { non-exercise } \\
\text { control }\end{array}$ & $\begin{array}{l}16 \text { weeks } \\
3 \text { days/week }\end{array}$ & $\begin{array}{l}60 \% \max \mathrm{HR} \\
90 \% \max \mathrm{HR}\end{array}$ & $70-75 \% \max H R$ \\
\hline Conraads et $\mathrm{al}^{42}$ & 85 & 89 & $\begin{array}{l}12 \text { weeks } \\
3 \text { days/week }\end{array}$ & $\begin{array}{l}\text { 90-95\% HR peak (prescribed) } \\
88 \% \text { HR peak (actual) }\end{array}$ & $\begin{array}{l}70-75 \% \text { HR peak (prescribed) } \\
80 \% \text { HR peak (actual) }\end{array}$ \\
\hline Currie et $\mathrm{al}^{43}$ & 9 & 10 & $\begin{array}{l}12 \text { weeks } \\
2 \text { days/week }\end{array}$ & $\begin{array}{l}75-95 \% \text { peak power output I } \\
\text { minute }\end{array}$ & $\begin{array}{l}51-65 \% \text { peak power } \\
\text { output }\end{array}$ \\
\hline Kim et $\mathrm{al}^{44}$ & 14 & 14 & $\begin{array}{l}6 \text { weeks } 3 \text { days/ } \\
\text { week }\end{array}$ & $\begin{array}{l}85-95 \% \text { HRR } \\
\text { and } 50-70 \% \text { HRR }\end{array}$ & $70-85 \%$ HRR \\
\hline Jaureguizar et $\mathrm{al}^{45}$ & 36 & 36 & $\begin{array}{l}8 \text { weeks } \\
3 \text { days/week }\end{array}$ & $\begin{array}{l}\text { Month I } \\
\text { I04.5 } \pm 22.2 \% \mathrm{VO}_{2} \text { peak } \\
\text { Month } 2 \\
134.5 \pm 29.7 \% \\
\mathrm{VO}_{2} \text { peak }\end{array}$ & $\begin{array}{l}\text { Month } \mathrm{I} \\
64.2 \pm 8.5 \mathrm{VO}_{2} \text { peak } \\
\text { Month } 2 \\
69.5 \pm 8.7 \mathrm{VO}_{2} \text { peak }\end{array}$ \\
\hline $\begin{array}{l}\text { Möbius-Winkler } \\
\text { et } \mathrm{al}^{46}\end{array}$ & 20 & $\begin{array}{l}20 \\
20 \text { (control } \\
\text { group) }\end{array}$ & $\begin{array}{l}4 \text { weeks } \\
5 \times \text { week }\end{array}$ & $\begin{array}{l}95 \% \text { angina-free threshold } \\
\text { Interspersed with } 70 \% \text { angina-free } \\
\text { threshold } \\
\text { I hour recovery between sessions }\end{array}$ & $60 \%$ angina-free threshold \\
\hline Prado et $\mathrm{al}^{47}$ & 17 & 18 & $\begin{array}{l}12 \text { weeks } \\
3 \text { days/week }\end{array}$ & $\begin{array}{l}7 \times 3 \text { minutes respiratory } \\
\text { compensation point } \\
\text { and } 3 \text { minutes } \mathrm{VT} \text { anaerobic }\end{array}$ & VT anaerobic threshold \\
\hline
\end{tabular}

Abbreviations: HIIT, high-intensity interval training; MICT, moderate-intensity continuous training; HR peak, heart rate peak; max HR, maximal heart rate; HRR, heart rate reserve; $\mathrm{VO}_{2}$ peak; peak oxygen uptake; $\mathrm{VT}$, ventilatory threshold.

\section{Strengths of the review}

There were a number of strengths to our review. To our knowledge, our review and meta-analysis has included the most number of trials to date, including studies not previously published in a review. Furthermore, our review and meta-analysis has the most up-to-date search date (end of July 2017), minimal heterogeneity, and investigated the effect of different durations of intervention on cardiorespiratory changes. We used a random effects model to cater to the different methodologies used to assess 


\begin{tabular}{|c|c|c|c|c|c|c|}
\hline \multirow[t]{2}{*}{$\begin{array}{l}\text { Protocol } \\
\text { HIIT }\end{array}$} & \multirow[t]{2}{*}{$\begin{array}{l}\text { Protocol } \\
\text { MICT }\end{array}$} & \multicolumn{2}{|l|}{$\begin{array}{l}\text { HIIT } \\
\mathrm{mL} / \mathrm{kg} / \mathrm{min} \\
(\mathrm{mean} \pm \mathrm{SD})\end{array}$} & \multicolumn{2}{|c|}{$\begin{array}{l}\text { MICT } \\
\mathrm{mL} / \mathrm{kg} / \mathrm{min} \\
(\mathrm{mean} \pm \mathrm{SD})\end{array}$} & \multirow{2}{*}{$\begin{array}{l}\text { Change in } \\
\mathrm{V}_{2 \text { peak }} \\
\mathrm{mL} / \mathrm{kg} / \mathrm{min} \\
(\mathrm{mean} \pm \mathrm{SD})\end{array}$} \\
\hline & & $\mathrm{VO}_{\text {2peak }}$ Pre & $\mathrm{VO}_{2 \text { peak }}$ Post & $\mathrm{VO}_{2 \text { peak }}$ Pre & $\mathrm{VO}_{\text {2peak }}$ Post & \\
\hline 5 minutes warm up & 5 minutes warm up & $22.4 \pm 4.2$ & $26 \pm 5.9$ & $21.8 \pm 4$ & $23.5 \pm 4.6$ & HIIT: $3.6 \pm 3.1$ \\
\hline 3 minutes $60-70 \%$ HRR & Treadmill & & & & & MICT: I.7 $\pm I .7$ \\
\hline $4 \times 4$ minutes $80-90 \%$ & 30 minutes aerobic & & & & & \\
\hline \multicolumn{7}{|l|}{ HRR: 3 minutes $60-70 \%$} \\
\hline \multicolumn{7}{|l|}{4 minutes cool down } \\
\hline \multicolumn{7}{|l|}{ Treadmill } \\
\hline 2 minutes: 2 minutes & Continuous aerobic & $20.6 \pm 5$ & $24.4 \pm 5$ & $21.8 \pm 6$ & $21.9 \pm 6$ & HIIT: $3.8 \pm 12.35$ \\
\hline treadmill & exercise & & & & & MICT: $0.1 \pm 12.355$ \\
\hline \multirow[t]{2}{*}{30 minutes } & Treadmill & & & & & \\
\hline & 30 minutes & & & & & \\
\hline \multirow[t]{5}{*}{ Bicycle } & Bicycle & $23.5 \pm 5.7$ & 6 weeks & $22.4 \pm 5.6$ & 6 weeks & HIIT: $3.4 \pm 4.7$ (6 weeks) \\
\hline & & & $26.7 \pm 6.7$ & & $25.2 \pm 6.2$ & $5.1 \pm 4.0$ ( 12 weeks $)$ \\
\hline & & & 12 weeks & & 12 weeks & MICT: \\
\hline & & & $28.6 \pm 6.9$ & & $26.6 \pm 6.7$ & $2.8 \pm 2.7$ (6 weeks) \\
\hline & & & & & & $4.4 \pm 3.3$ ( 12 weeks $)$ \\
\hline 10 minute warm up and & 5 minutes warm up and & $21.1 \pm 3.3$ & 12 weeks & $19.8 \pm 7.3$ & 12 weeks & HIIT: 12 weeks \\
\hline 3 min cool down & cool down & & $26.4 \pm 5.2$ & & $23.2 \pm 7.4$ & $5.275 \pm 2.954$ \\
\hline \multirow[t]{6}{*}{ Total: 38 minutes } & 37 minutes exercise & & 6 months & & 6 months & 6 months \\
\hline & time & & $27.2 \pm 6$ & & $24.2 \pm 7.8$ & $5.908 \pm 3.587$ \\
\hline & Total: 47 minutes & & & & & MICT: 12 weeks \\
\hline & & & & & & $3.762 \pm 3.168$ \\
\hline & & & & & & 6 months \\
\hline & & & & & & $5.148 \pm 5.742$ \\
\hline First 3 sessions MICT & 10 minutes warm up & $29.15 \pm 5.46$ & $35.6 I \pm 7.71$ & $27.12 \pm 8.19$ & $29.59 \pm 8.65$ & HIIT: 12 weeks \\
\hline 10 minutes warm up & 25 minutes walk & & & & & $6.46 \pm 4.296$ \\
\hline $4 \times 4$ minutes & 10 minutes cool down & & & & & МICT: $2.47 \pm 4.296$ \\
\hline treadmill & Treadmill & & & & & \\
\hline 10 minutes cool down & Total: 45 minutes & & & & & \\
\hline \multicolumn{7}{|l|}{ Total: 45 minutes } \\
\hline Steep ramp test on cycle & Bicycle & $19.4 \pm 4.7$ & $24 \pm 4.8$ & $20.3 \pm 5$ & $22.8 \pm 6.5$ & HIIT: $4.5 \pm 4.7$ \\
\hline $25 \mathrm{~W}$ increment & & & & & & MICT: $2.5 \pm 3.6$ \\
\hline \multicolumn{7}{|l|}{ then 20 seconds @ } \\
\hline \multicolumn{7}{|l|}{$50 \%$ steep ramp test: 40} \\
\hline \multicolumn{7}{|l|}{ seconds recovery at $10 \%$} \\
\hline $4 \times$ day & $6-8 \times$ day & $23.1 \pm 5.2$ & $26.1 \pm 5.7$ & $22.8 \pm 4.8$ & $27 \pm 5.9$ & HIIT: $3 . I \pm 2.34$ \\
\hline 30 minutes per session & 20 minutes per session & & & & & MICT: $3.88 \pm 3.01$ \\
\hline Not stated & multimodal & & & & & \\
\hline & intervention & & & & & \\
\hline 5 minutes warm up and & 5 minutes warm up and & $17.9 \pm 1$ & $22.3 \pm 1.1$ & $18.8 \pm 1.2$ & $23 \pm 1.3$ & HIIT: $4.4 \pm 8.5578$ \\
\hline cool down & cool down & & & & & MICT: $4.2 \pm 8.4458$ \\
\hline treadmill & treadmill & & & & & \\
\hline 42 minutes & 50 minutes & & & & & \\
\hline
\end{tabular}

cardiorespiratory fitness as well as the different modes of exercise intervention. Moreover, we used a conservative approach when calculating standard deviations. Upon inspection of the funnel plot (Figure 3), publication bias does not appear to be a concern as all studies fell within the acceptable range.
Previously published meta-analyses have had high heterogeneity ${ }^{16-18}$ and did not publish adequate methodology surrounding standard deviation measurements. ${ }^{17,18}$ They did not cater for differences in exercise intervention and cardiorespiratory fitness testing, as a fixed-effect model of statistical analysis was used. In addition, our research questions 
Table 3 Quality analysis using PEDro-scale

\begin{tabular}{|c|c|c|c|c|c|c|c|c|c|}
\hline RCT & $\begin{array}{l}\text { Random } \\
\text { allocation }\end{array}$ & $\begin{array}{l}\text { Concealed } \\
\text { allocation }\end{array}$ & $\begin{array}{l}\text { Baseline } \\
\text { similarities } \\
\text { between } \\
\text { groups }\end{array}$ & $\begin{array}{l}\text { Blinding of } \\
\text { assessors }\end{array}$ & $\begin{array}{l}\text { Outcome } \\
\text { measure } \\
\text { from } \\
>85 \% \\
\text { subjects }\end{array}$ & $\begin{array}{l}\text { Intention } \\
\text { to treat }\end{array}$ & $\begin{array}{l}\text { Between } \\
\text { group } \\
\text { statistical } \\
\text { comparison }\end{array}$ & $\begin{array}{l}\text { Point } \\
\text { measures } \\
\text { and } \\
\text { measures of } \\
\text { variability }\end{array}$ & $\begin{array}{l}\text { Total } \\
\text { score } \\
(18)\end{array}$ \\
\hline Jensen et $\mathrm{a}^{31}$ & $\checkmark$ & $x$ & $\checkmark$ & $x$ & $\checkmark$ & $\checkmark$ & $\checkmark$ & $\checkmark$ & 6 \\
\hline Rognmo et $\mathrm{al}^{32}$ & $\checkmark$ & $\checkmark$ & $\checkmark$ & $x$ & $x$ & $\checkmark$ & $\checkmark$ & $\checkmark$ & 5 \\
\hline Warburton et $\mathrm{a}^{33}$ & $\checkmark$ & $x$ & $\checkmark$ & $x$ & $\checkmark$ & $\checkmark$ & $\checkmark$ & $\checkmark$ & 6 \\
\hline Amundsen et $\mathrm{al}^{34}$ & $\checkmark$ & $x$ & $\checkmark$ & $x$ & $x$ & $x$ & $\checkmark$ & $\checkmark$ & 4 \\
\hline Moholdt et al ${ }^{35}$ & $\checkmark$ & $x$ & $\checkmark$ & $\checkmark$ & $x$ & $x$ & $\checkmark$ & $\checkmark$ & 5 \\
\hline Benetti et $\mathrm{a}^{36}$ & $\checkmark$ & $x$ & $\checkmark$ & $x$ & $\checkmark$ & $x$ & $\checkmark$ & $\checkmark$ & 5 \\
\hline Moholdt et $\mathrm{al}^{37}$ & $\checkmark$ & $\checkmark$ & $\checkmark$ & $x$ & $x$ & $x$ & $\checkmark$ & $\checkmark$ & 5 \\
\hline Rocco et $\mathrm{al}^{38}$ & $\checkmark$ & $x$ & $\checkmark$ & $x$ & $x$ & $x$ & $\checkmark$ & $\checkmark$ & 3 \\
\hline Currie et $\mathrm{a}^{39}$ & $\checkmark$ & $x$ & $\checkmark$ & $x$ & $x$ & $x$ & $\checkmark$ & $\checkmark$ & 4 \\
\hline Keteyian et al ${ }^{40}$ & $\checkmark$ & $\checkmark$ & $\checkmark$ & $\checkmark$ & $x$ & $x$ & $\checkmark$ & $\checkmark$ & 6 \\
\hline Cardozo et $\mathrm{a}^{41}$ & $\checkmark$ & $x$ & $\checkmark$ & $x$ & $\checkmark$ & $\checkmark$ & $\checkmark$ & $\checkmark$ & 6 \\
\hline Conraads et $\mathrm{a}^{42}$ & $\checkmark$ & $x$ & $x$ & $x$ & $\checkmark$ & $\checkmark$ & $\checkmark$ & $\checkmark$ & 5 \\
\hline Currie et $\mathrm{al}^{43}$ & $\checkmark$ & $x$ & $\checkmark$ & $x$ & $x$ & $x$ & $\checkmark$ & $\checkmark$ & 4 \\
\hline Kim et $\mathrm{al}^{44}$ & $\checkmark$ & $x$ & $\checkmark$ & $x$ & $\checkmark$ & $x$ & $\checkmark$ & $\checkmark$ & 5 \\
\hline Jaureguizar et $\mathrm{a}^{45}$ & $\checkmark$ & $x$ & $\checkmark$ & $\checkmark$ & $\checkmark$ & $x$ & $\checkmark$ & $\checkmark$ & 6 \\
\hline Möbius-Winkler et al ${ }^{46}$ & $\checkmark$ & $x$ & $\checkmark$ & $x$ & $\checkmark$ & $x$ & $\checkmark$ & $\checkmark$ & 5 \\
\hline Prado et $\mathrm{a}^{47}$ & $\checkmark$ & $x$ & $\checkmark$ & $x$ & $\checkmark$ & $\checkmark$ & $\checkmark$ & $\checkmark$ & 6 \\
\hline
\end{tabular}

Abbreviations: PEDro, the physiotherapy evidence-based database; RCT, randomized controlled trial.

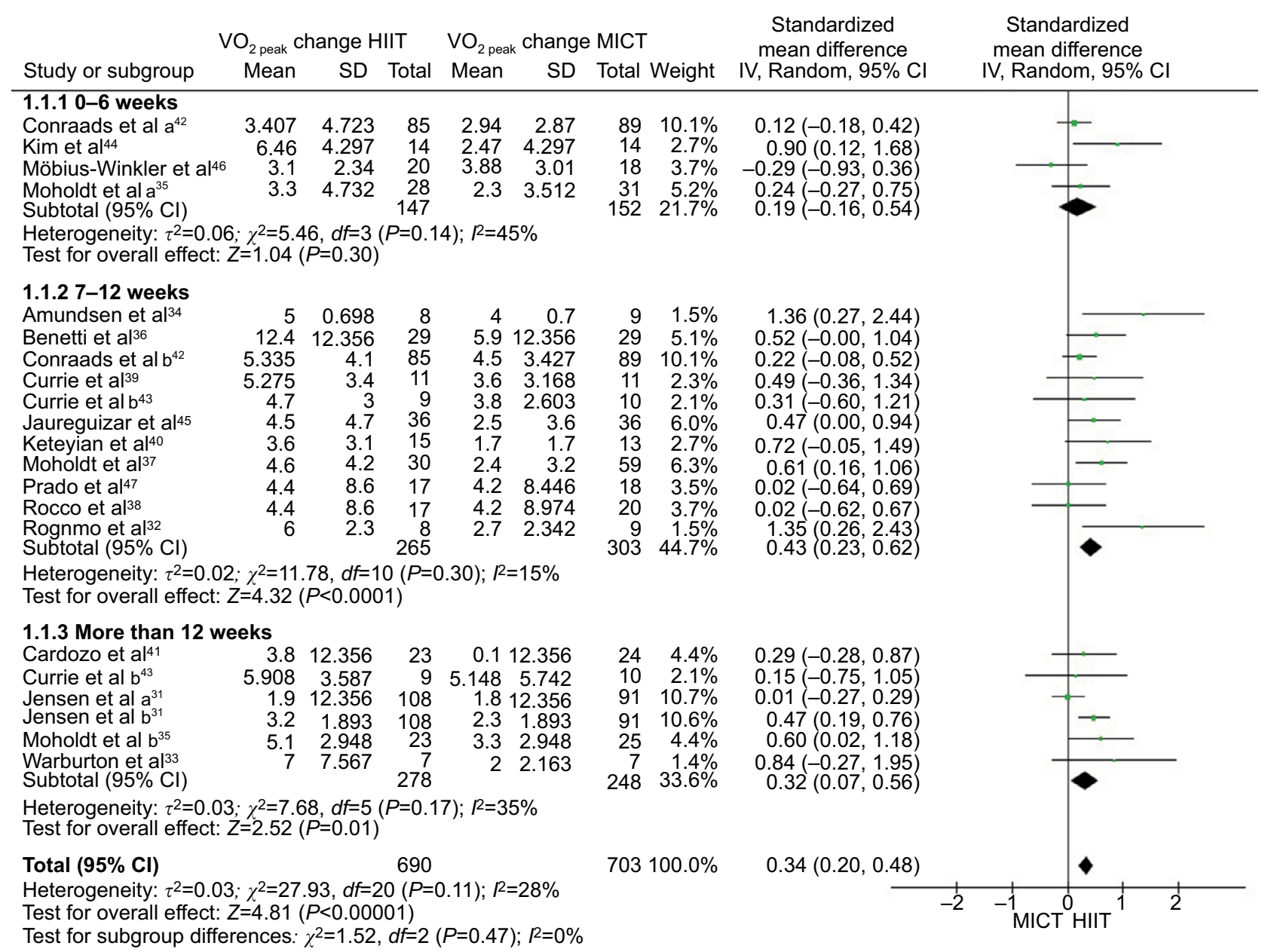

Figure 2 Forest plots depicting aerobic capacity changes as a result of HIIT versus MICT (standard mean difference in $\mathrm{mL} / \mathrm{kg} / \mathrm{min}$ ).

Abbreviations: HIIT, high-intensity interval training; MICT, moderate-intensity continuous training; IV, inverse variance; Cl, confidence interval; SD, standard deviation. 


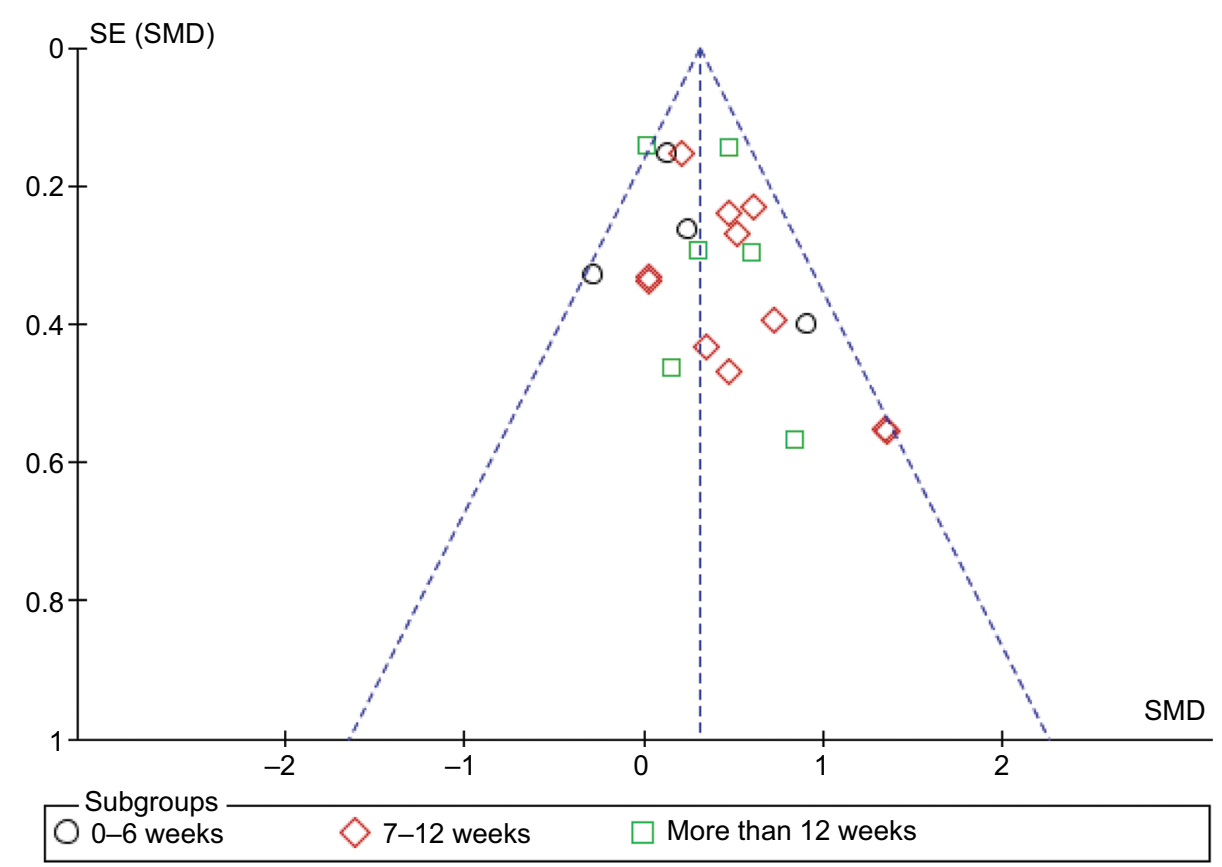

Figure 3 Funnel plot of publication bias.

surrounding effects of duration of interventions could not be answered by previous reviews; therefore this systematic review and meta-analysis was required.

\section{Limitations}

There were some limitations to our review. The search used databases which have been used in previous systematic reviews; therefore, the Cochrane Database was not searched. This systematic review included the recent study by Conraads et al, ${ }^{42}$ which involved 200 patients with CAD and compared aerobic capacity changes between HIIT and MICT. The authors found similar improvements between groups. HIIT participants were prescribed exercise at $90-95 \%$ peak heart rate and MICT participants exercised at 70-75\% peak heart rate; however, the authors acknowledged that the MICT group exercised closer to $80 \%$ peak heart rate and the HIIT group closer to $88 \%$ peak heart rate. ${ }^{42}$ The higher intensity used by the MICT exercisers and lower intensities for the HIIT participants may account for the non-significant results. This study was heavily weighted in the meta-analysis and may have contributed to the overall underestimation of the gains in cardiorespiratory fitness that may be potentially gained from HIIT. This, coupled with our conservative approach, may be disadvantaging the actual degree of cardiorespiratory fitness changes that can be contributed to HIIT and, perhaps, reduce the likelihood of its uptake. No studies reported using a specific protocol to collate adverse events and, therefore, recording of some adverse events may have been missed.

\section{Future directions}

Future studies would benefit from being between 7- and 12-week duration and undertaking the intervention at least three times a week, ensuring correct intensity is maintained (eg, $\geq 85 \% \mathrm{VO}_{2}$ peak or $\geq 85 \%$ HRR or $\geq 90 \% \mathrm{HRM}$ ) interspersed with lower level exercise and MICT (50-75\% $\mathrm{VO}_{2}$ peak or $50-75 \%$ HRR or $50-80 \%$ HRM). This would allow a more accurate calculation of the true effects of HIIT versus MICT on cardiorespiratory fitness. Studies should report standard deviations, conceal allocation, and blind assessors to improve study quality. Moreover, future studies should aim to recruit more women and older participants ( $<76$ years) to ensure HIIT is more effective than MICT in improving cardiorespiratory fitness for a broader range of CR participants. Finally, further studies that investigate the longer term benefits of HIIT and whether these adaptations are maintained would also be beneficial.

\section{Conclusion}

This study confirms that HIIT is significantly superior to MICT in improving cardiorespiratory fitness. When conducting a subgroup analysis, it was shown that interventions lasting $>7$ weeks resulted in greater improvements in cardiorespiratory fitness in CR patients with CAD. This improvement does not appear to increase after 12-week duration. Moreover, this study shows that HIIT appears to be as safe as MICT as an exercise intervention tool for CR participants. This review may allow countries with guidelines 
Table 4 Summary of randomized controlled trials' adverse events using aerobic MICT versus HIIT for patients with coronary artery disease

\begin{tabular}{|c|c|c|c|c|c|}
\hline RCT study & $\begin{array}{l}\text { Cardiac } \\
\text { adverse events } \\
\text { reported HIIT }\end{array}$ & $\begin{array}{l}\text { Cardiac adverse } \\
\text { events reported } \\
\text { MICT }\end{array}$ & $\begin{array}{l}\text { Other adverse } \\
\text { events } \\
\text { HIIT }\end{array}$ & $\begin{array}{l}\text { Other adverse events } \\
\text { MICT }\end{array}$ & $\begin{array}{l}\text { Events recorded } \\
\text { but not classified by } \\
\text { intensity }\end{array}$ \\
\hline Jensen et $\mathrm{al}^{31}$ & $\begin{array}{l}\text { Events not } \\
\text { reported }\end{array}$ & Events not reported & Events not reported & Events not reported & Events not reported \\
\hline Rognmo et $\mathrm{al}^{32}$ & Nil events & Nil events & I ankle fracture & I knee injury & Nil events \\
\hline Warburton et $\mathrm{al}^{33}$ & Nil events & Nil events & Nil events & Nil events & Nil events \\
\hline Amundsen et $\mathrm{al}^{34}$ & Nil events & Nil events & Nil events & Nil events & $\begin{array}{l}\text { Physical impairment not } \\
\text { related to cardiovascular } \\
\text { disease }\end{array}$ \\
\hline Moholdt et $\mathrm{al}^{35}$ & Nil events & Nil events & $\begin{array}{l}\text { Leg pain, hip pain, } \\
\text { bronchitis }\end{array}$ & $\begin{array}{l}\text { Readmitted to hospital } \\
\text { (reason not reported), } \\
\text { pericardial effusion }\end{array}$ & Nil events \\
\hline Benetti et $\mathrm{al}^{36}$ & Nil events & Nil events & Nil events & Nil events & $\begin{array}{l}\text { Unstable angina } \times 2 \\
\text { joint problems }\end{array}$ \\
\hline Moholdt et $\mathrm{al}^{37}$ & $\begin{array}{l}\text { Angina caused } \\
\text { drop out }\end{array}$ & Angina caused drop out & $\begin{array}{l}\text { Gastroenteritis, } \\
\text { pancreatitis, } \\
\text { intermittent } \\
\text { claudication }\end{array}$ & $\begin{array}{l}\text { Gastrointestinal bleeds, } \\
\text { bronchitis, knee } \\
\text { surgery, low back pain, } \\
\text { psychiatric disease }\end{array}$ & Nil events \\
\hline Rocco et $\mathrm{al}^{38}$ & $\begin{array}{l}\text { Events not } \\
\text { reported }\end{array}$ & Events not reported & Events not reported & Events not reported & Events not reported \\
\hline Currie et $\mathrm{al}^{39}$ & Nil events & Nil events & Nil events & $\begin{array}{l}\text { I } \times \text { musculoskeletal } \\
\text { injury unrelated to } \\
\text { training caused inability } \\
\text { to perform post-training } \\
\text { test }\end{array}$ & Nil event \\
\hline Keteyian et $\mathrm{al}^{40}$ & Nil events & Nil events & $\begin{array}{l}\text { Knee pain } \times 1 \\
\text { requiring } 2 \text {-week rest }\end{array}$ & I $\times$ limiting leg pain & Nil events \\
\hline Cardozo et $\mathrm{al}^{4 \mathrm{I}}$ & Nil events & Nil events & Nil events & Nil events & Nil events \\
\hline Conraads et $\mathrm{al}^{42}$ & Nil events & $\begin{array}{l}\text { Nil events during training } \\
\text { I acute } \mathrm{MI} \text { requiring } \mathrm{PCl} \\
\text { greater than } 24 \text { hours } \\
\text { post training. } \\
\text { Two episodes of significant } \\
\text { ST depression was seen } \\
\text { on exercise testing } 6 \\
\text { weeks post training. Both } \\
\text { required } \mathrm{PCl} \text {. }\end{array}$ & Nil events & Nil events & Nil events \\
\hline Currie et $\mathrm{al}^{43}$ & $\begin{array}{l}\text { Events not } \\
\text { reported }\end{array}$ & Events not reported & Events not reported & Events not reported & Events not reported \\
\hline Kim et $\mathrm{al}^{44}$ & Nil events & Nil events & Nil events & Nil events & Nil events \\
\hline Jaureguizar et $\mathrm{al}^{45}$ & Nil events & Nil events & Nil events & Nil events & Nil events \\
\hline $\begin{array}{l}\text { Möbius-Winkler } \\
\text { et } \mathrm{al}^{46}\end{array}$ & Nil events & Nil events & Nil events & Nil events & $\begin{array}{l}\text { Progression of } \mathrm{CAD} \times \mathrm{I} \\
\text { after } 4 \text { weeks training and } \\
\text { increased angina requiring } \\
\mathrm{PCl}\end{array}$ \\
\hline Prado et $\mathrm{al}^{47}$ & $\begin{array}{l}\text { Events not } \\
\text { reported }\end{array}$ & Events not reported & Events not reported & Events not reported & Events not reported \\
\hline
\end{tabular}

that recommend lower intensity exercise more confidence in including HIIT within their guidelines and improving international consensus.

\section{Disclosure}

The authors report no conflicts of interest in this work and the research did not receive any specific grant from funding agencies in the public, commercial, or not-forprofit sectors.

\section{References}

1. Lozano R, Naghavi M, Foreman K, et al. Global and regional mortality from 235 causes of death for 20 age groups in 1990 and 2010: a systematic analysis for the Global Burden of Disease Study 2010. Lancet. 2012;380(9859):2095-2128. 
2. Heran BS, Chen JM, Ebrahim S, et al. Exercise-based cardiac rehabilitation for coronary heart disease. Cochrane Database Syst Rev. 2011;(7):CD001800.

3. Taylor RS, Brown A, Ebrahim S, et al. Exercise-based rehabilitation for patients with coronary heart disease: systematic review and metaanalysis of randomized controlled trials. Am J Med. 2004;116(10): 682-692.

4. National Heart Foundation of Australia. Secondary prevention of cardiovascular disease. 2010. Available from: http://heartfoundation.org au/. Accessed August 1, 2017.

5. Anderson L, Thompson DR, Oldridge N, et al. Exercise-based cardiac rehabilitation for coronary artery disease. Cochrane Database Syst Rev. 2016(1):CD001800.

6. Price KJ, Gordon BA, Bird SR, Benson AC. A review of guidelines for cardiac rehabilitaiton exercise programmes: is there an international consensus? Eur J Prev Cardiol. 2016;23(16):1715-1733.

7. Woodruffe S, Neubeck L, Clark RA, et al. Australian Cardiovascular Health and Rehabilitation Association (ACRA) core components of cardiovascular disease secondary prevention and cardiac rehabilitation 2014. Heart Lung Circ. 2015;24(5):430-441.

8. Scottish Intercollegiate Guidelines Network (SIGN). Cardiac Rehabilitation. A National Clinical Guideline. Edinburgh, Scotland: Sign; 2002.

9. Mezzani A, Hamm LF, Jones AM, et al. Aerobic exercise intensity assessment and prescription in cardiac rehabilitation: a joint position statement of the European Association for Cardiovascular Prevention and Rehabilitation, the American Association of Cardiovascular and Pulmonary Rehabilitation and the Canadian Association of Cardiac Rehabilitation. Eur J Prev Cardiol. 2013;20(3):442-467.

10. American College of Sports Medicine. ACSM's Guidelines for Exercise Testing and Prescription. 9th ed. Philadelphia: Lippincott Williams \& Wilkins; 2013.

11. Myers J, Prakash M, Froelicher V, Do D, Partington S, Atwood JE. Exercise capacity and mortality among men referred for exercise testing. N Engl J Med. 2002;346(11):793-801.

12. Swain DP, Franklin BA. Comparison of cardioprotective benefits of vigorous versus moderate intensity aerobic exercise. Am J Cardiol. 2006;97(1):141-147.

13. Keteyian SJ, Brawner CA, Savage PD, et al. Peak aerobic capacity predicts prognosis in patients with coronary heart disease. Am Heart $J$. 2008;156(2):292-300.

14. Ehsani AA, Heath GW, Hagberg JM, Sobel BE, Holloszy JO. Effects of 12 months of intense exercise training on ischemic ST-segment depression in patients with coronary artery disease. Circulation. 1981;64(6):1116-1124.

15. Cornish AK, Broadbent $\mathrm{S}$, Cheema BS. Interval training for patients with coronary artery disease: a systematic review. Eur J Appl Physiol. 2011;111(4):579-589.

16. Pattyn N, Coeckelberghs E, Buys R, Cornelissen VA, Vanhees L. Aerobic interval training vs. moderate continuous training in coronary artery disease patients: a systematic review and meta-analysis. Sports Med. 2014;44(5):687-700.

17. Elliott AD, Rajopadhyaya K, Bentley DJ, Beltrame JF, Aromataris EC. Interval training versus continuous exercise in patients with coronary artery disease: a meta-analysis. Heart Lung Circ. 2015;24(2) 149-157.

18. Liou K, Ho S, Fildes J, Ooi SY. High intensity interval versus moderate intensity continuous training in patients with coronary artery disease: a meta-analysis of physiological and clinical parameters. Heart Lung Circ. 2016;25(2):166-174.

19. Kessler HS, Sisson SB, Short KR. The potential for high-intensity interval training to reduce cardiometabolic disease risk. Sports Med. 2012;42(6):489-509.

20. Gibala MJ, Little JP, Macdonald MJ, Hawley JA. Physiological adaptations to low-volume, high intensity interval training in health and disease. J Physiol. 2012;590(5):1077-1084.

21. Boutcher SH. High-intensity intermittent exercise and fat loss. J Obes. 2011;2011:868305.
22. Rognmo Ø, Moholdt T, Bakken H, et al. Cardiovascular risk of highversus moderate-intensity aerobic exercise in coronary heart disease patients. Circulation. 2012;126(12):1436-1440.

23. Booth A, Clarke M, Dooley G, et al. The nuts and bolts of PROSPERO: an international prospective register of systematic reviews. Syst Rev. 2012;1:2.

24. Moher D, Liberati A, Tetzlaff J, Altman DG; PRISMA Group. Preferred reporting items for systematic reviews and meta-analyses:the PRISMA statement. Ann Intern Med. 2009;151(4):264-269, W64.

25. Verhagen AP, de Vet HC, de Bie RA, et al. The Delphi list: a criteria list for quality assessment of randomized clinical trials for conducting systematic reviews developed by Delphi consensus. J Clin Epidemiol. 1998;51(12):1235-1241.

26. Kennelly J. Methodological Approach to Assessing the Evidence. In: Handler A, Kennelly J, Peacock N, editors. Reducing Racial/Ethnic Disparities in Reproductive and Perinatal Outcomes. Boston, MA: Springer; 2011.

27. Lyons K, Radburn C, Orr R, Pope R. A profile of injuries sustained by law enforcement officers: a critical review. Int J Environ Res Public Health. 2017;14(2). pii: E142.

28. Higgins JPT, Green S. Cochrane Handbook for Systematic Reviews of Interventions. Version 5.1. Oxford: Cochrane Collaboration; 2011.

29. Simas V, Hing W, Pope R, Climstein M. Effects of water-based exercise on bone health of middle-aged and older adults: a systematic review and meta-analysis. Open Access J Sports Med. 2017;8:39-60.

30. Higgins JP, Altman DG, Gøtzsche PC; Cochrane Bias Methods Group; Cochrane Statistical Methods Group. The Cochrane Collaboration's tool for assessing risk of bias in randomised trials. BMJ. 2011:343:d5928.

31. Jensen BE, Fletcher BJ, Rupp JC, Fletcher GF, Lee JY, Oberman A. Training level comparison study. Effect of high and low intensity exercise on ventilatory threshold in men with coronary artery disease. J Cardiopulm Rehabil. 1996;16(4):227-232.

32. Rognmo Ø, Hetland E, Helgerud J, Hoff J, Slørdahl SA. High intensity aerobic interval exercise is superior to moderate intensity exercise for increasing aerobic capacity in patients with coronary artery disease. Eur J Cardiovasc Prev Rehabil. 2004;11(3):216-222.

33. Warburton DE, McKenzie DC, Haykowsky MJ, et al. Effectiveness of high-intensity interval training for the rehabilitation of patients with coronary artery disease. Am J Cardiol. 2005;95(9):1080-1084.

34. Amundsen BH, Rognmo $\varnothing$, Hatlen-Rebhan G, Slørdahl SA. Highintensity aerobic exercise improves diastolic function in coronary artery disease. Scand Cardiovasc J. 2008;42(2):110-117.

35. Moholdt TT, Amundsen BH, Rustad LA, et al. Aerobic interval training versus continuous moderate exercise after coronary artery bypass surgery: a randomized study of cardiovascular effects and quality of life. Am Heart J. 2009;158(6):1031-1037.

36. Benetti M, Araujo CL, Santos RZ. Cardiorespiratory fitness and quality of life at different exercise intensities after myocardial infarction. Arq Bras Cardiol. 2010;95(3):399-404.

37. Moholdt T, Aamot IL, Granøien I, et al. Aerobic interval training increases peak oxygen uptake more than usual care exercise training in myocardial infarction patients: a randomized controlled study. Clin Rehabil. 2012;26(1):33-44.

38. Rocco EA, Prado DM, Silva AG, et al. Effect of continuous and interval exercise training on the PETCO2 response during a graded exercise test in patients with coronary artery disease. Clinics (Sao Paulo). 2012;67(6):623-628.

39. Currie KD, Dubberley JB, McKelvie RS, MacDonald MJ. Low-volume, high-intensity interval training in patients with CAD. Med Sci Sports Exerc. 2013;45(8):1436-1442.

40. Keteyian SJ, Hibner BA, Bronsteen K, et al. Greater improvement in cardiorespiratory fitness using higher-intensity interval training in the standard cardiac rehabilitation setting. J Cardiopulm Rehabil Prev. 2014;34(2):98-105.

41. Cardozo GG, Oliveira RB, Farinatti PT. Effects of high intensity interval versus moderate continuous training on markers of ventilatory and cardiac efficiency in coronary heart disease patients. ScientificWorldJournal. 2015;2015:192479. 
42. Conraads VM, Pattyn N, De Maeyer C, et al. Aerobic interval training and continuous training equally improve aerobic exercise capacity in patients with coronary artery disease: the SAINTEX-CAD study. Int $J$ Cardiol. 2015;179:203-210.

43. Currie KD, Bailey KJ, Jung ME, McKelvie RS, MacDonald MJ. Effects of resistance training combined with moderate-intensity endurance or low-volume high-intensity interval exercise on cardiovascular risk factors in patients with coronary artery disease. J Sci Med Sport. 2015;18(6): 637-642.

44. Kim C, Choi HE, Lim MH. Effect of high interval training in acute myocardial infarction patients with drug-eluting stent. Am J Phys Med Rehabil. 2015;94(10 Suppl 1):879-886.

45. Jaureguizar KV, Vicente-Campos D, Bautista LR, et al. Effect of highintensity interval versus continuous exercise training on functional capacity and quality of life in patients with coronary artery disease: a randomized clinical trial. J Cardiopulm Rehabil Prev. 2016;36(2):96-105.

46. Möbius-Winkler S, Uhlemann M, Adams V, et al. Coronary collateral growth induced by physical exercise: results of the impact of intensive exercise training on coronary collateral circulation in patients with stable coronary artery disease (EXCITE) trial. Circulation. 2016;133(15): 1438-1448.
47. Prado DM, Rocco EA, Silva AG, et al. Effects of continuous vs interval exercise training on oxygen uptake efficiency slope in patients with coronary artery disease. Braz J Med Biol Res. 2016;49(2):e4890.

48. Pattyn N, Vanhees L, Cornelissen VA, et al. The long-term effects of a randomized trial comparing aerobic interval versus continuous training in coronary artery disease patients: 1-year data from the SAINTEXCAD study. Eur J Prev Cardiol. 2016;23(11):1154-1164.

49. Biddle SJ, Batterham AM. High-intensity interval exercise training for public health: a big HIT or shall we HIT it on the head?. Int J Behav Nutr Phys Act. 2015;12:95.

50. Jung ME, Bourne JE, Beauchamp MR, Robinson E, Little JP. Highintensity interval training as an efficacious alternative to moderateintensity continuous training for adults with prediabetes. J Diabetes Res. 2015;2015:191595.

51. Thum JS, Parsons G, Whittle T, Astorino TA. High-intensity interval training elicits higher enjoyment than moderate intensity continuous exercise. PLoS One. 2017;12(1):e0166299.

52. Martinez N, Kilpatrick MW, Salomon K, Jung ME, Little JP. Affective and enjoyment responses to high-intensity interval training in overweight-to-obese and insufficiently active adults. J Sport Exerc Psychol. 2015;37(2):138-149. 


\section{Supplementary material}

\section{Embase Search Strategy}

1. ("cardiac disease" or "heart disease" or "cardiovascular disease"):ab,ti,de or "heart disease'/de or

"myocardial infarction":ab,ti,de or "myocardial infarct":ab,ti,de or "heart attack":ab,ti,de or "heart infarction":ab,ti,de or "heart infarct":ab,ti,de or "heart infarction'/de or "cardiac arrest":ab,ti,de or "coronary artery disease":ab,ti,de or CAD:ab,ti,de or "coronary artery disease'/de or arteriosclerosis:ab,ti,de or 'arteriosclerosis'/de or atherosclerosis:ab,ti,de or 'atherosclerosis'/de or "coronary heart disease":ab,ti,de or "coronary disease":ab,ti,de or "coronary artery disease'/de or "ischaemic disease":ab,ti,de or "ischemic disease":ab,ti,de or "cardiac ischemia":ab,ti,de or "cardiac ischaemia":ab,ti,de or "myocardial ischemia":ab,ti,de or "myocardial ischaemia":ab,ti,de or 'heart muscle ischemia'/de or "ischemic heart disease": ab,ti,de or "ischaemic heart disease":ab,ti,de or IHD:ab,ti,de or "ischemic heart disease'/de or "angina":ab,ti,de or 'angina pectoris'/de or “coronary angioplasty":ab,ti,de or angioplasty:ab,ti,de or 'transluminal coronary angioplasty'/de or 'angioplasty'/de or balloon:ab,ti,de or "percutaneous coronary intervention":ab,ti,de or PCI:ab,ti,de or 'percutaneous coronary intervention'/de or (percutaneous and (heart or coronary or cardiac)):ab,ti,de or ((revascularisation or revascularization) and (heart or coronary or cardiac)):ab,ti,de or "acute coronary syndrome":ab,ti,de or 'acute coronary syndrome'/de

2. rehabilitat*:ab,ti,de or "rehabilitation'/de or 'rehabilitation center"/de or "physical therapy":ab,ti,de or physiotherapy:ab,ti,de or "physiotherapy'/de or kinesiotherap*:ab,ti,de or 'kinesiotherapy'/de or therap*:ab,ti,de

3. ("interval training" or "interval exercise" or "interval or continuous" or "moderate intensity continuous exercise") or (("high intensity" and (exercise or training)) or HIIT or HIIE or "vigorous intensity" or ("low volume" and (exercise or training)) or (intermittent N2 (training or exercise or continuous))):ab,ti,de

4. \#1 and \#2 and \#3

\section{Publish your work in this journal}

The Open Access Journal of Sports Medicine is an international, peer-reviewed, open access journal publishing original research, reports, reviews and commentaries on all areas of sports medicine. The journal is included on PubMed. The manuscript management system is completely online and includes a very quick and fair peer-review system. Visit http://www.dovepress.com/testimonials.php to read real quotes from published authors. 